\title{
Recombinant Sendai virus vectors for activated T lymphocytes
}

\author{
S Okano ${ }^{1}$, Y Yonemitsu ${ }^{1}$, S Nagata ${ }^{1}$, S Sata ${ }^{1}$, M Onimaru$^{1}$, K Nakagawa ${ }^{1}$, Y Tomita ${ }^{2}$, K Kishihara ${ }^{4}$, \\ S Hashimoto ${ }^{1}$, Y Nakashima ${ }^{1}$, K Sugimachi ${ }^{3}$, M Hasegawa ${ }^{5}$ and K Sueishi ${ }^{1}$ \\ ${ }^{1}$ Division of Pathophygiological and Experimental Pathology, Department of Pathology, Graduate School of Medical Sciences, Kyushu \\ University, Fukuoka, Japan; ${ }^{2}$ Department of Cardiovascular Surgery, Graduate School of Medical Sciences, Kyushu University, Fukuoka, \\ Japan; ${ }^{3}$ Department of Surgery and Science, Graduate School of Medical Sciences, Kyushu University, Fukuoka, Japan; ${ }^{4}$ Division of \\ Molecular and Cellular Immunology, Medical Institute of Bioregulation, Kyushu University, Fukuoka, Japan; and ${ }^{5}$ DNAVEC Research \\ Inc., Tsukuba-city, Ibaraki, Japan
}

\begin{abstract}
T-lymphocyte-directed gene therapy has potential as a treatment of subjects with immunological disorders. One current limitation of this therapeutic strategy is low gene transfer efficiency, even when complex procedures are used. We report herein that a recombinant Sendai virus vector (SeV) was able to overcome this issue. Using jellyfish enhanced green fluorescent protein gene (EGFP), we found that SeV was able to transduce and express a foreign gene specifically and efficiently in activated murine and human $T$ cells, but not in naive $T$ cells, without centrifugation or reagents including polybrene and protamine sulfate; the present findings were in clear contrast to those demonstrated
\end{abstract}

with the use of retroviruses. The transduction was selective in antigen-activated $T$ cells, while antigen-irrelevant $T$ cells were not transduced, even under bystander activation from specific $T$-cell responses by antigens ex vivo. Receptor saturation studies suggested a possible mechanism of activated T-cell-specific gene transfer, ie, SeV might attach to naive $T$ cells but might be unable to enter their cytoplasm. We therefore propose that the SeV vector system may prove to be a potentially important alternative in the area of T-celldirected gene therapy used in the clinical setting. Gene Therapy (2003) 10, 1381-1391. doi:10.1038/ sj.gt.3301998

Keywords: gene therapy; T cells; Sendai virus vector; enhanced green fluorescent protein gene

\section{Introduction}

Genetic modification of hematopoietic cells is a strategy to be considered when treating subjects with autoimmune diseases, immunodeficient states, as well as tumors. Among the various types of blood cells, $\mathrm{T}$ lymphocytes have been a target of gene transfer from the early stages of human gene therapy trials. ${ }^{1,2}$ However, $\mathrm{T}$ cells are relatively resistant to gene transfer using currently available vectors, including retroviruses. Although an encouraging human study using a retrovirus demonstrated the success of T-cell-directed gene therapy against severely combined immunodeficiency disease (SCID) owing to adenosine deaminase deficiency (ADA), ${ }^{1,3}$ it has been difficult to use this strategy in cases of other diseases, because the gene transfer efficiency is usually a critical factor limiting the outcome. Therefore, current efforts are now focused on the development of pseudotyped vectors ${ }^{4}$ and transduction techniques ${ }^{5-8}$ for the use of retroviral vectors for clinical applications.

Correspondence: $\operatorname{Dr} S$ Okano, Division of Pathophygiological and Experimental Pathology, Department of Pathology, Graduate School of Medical Sciences, Kyushu University, Maidashi 3-1-1, Higashi-ku, Fukuoka 812-8582, Japan

This work was supported by a Grant for the Promotion of Basic Scientific Research in the Medical Frontier of The Organization for Pharmaceutical Safety and Research

Received 18 September 2002; accepted 10 January 2003
When treating subjects with autoimmune diseases, allo-organ rejection after transplantation, or tumors, there is a subset of activated $\mathrm{T}$ lymphocytes that can be used as targets for gene modification. ${ }^{2,9,10}$ An early clinical report demonstrated that tumor infiltrating lymphocytes (TILs), which are activated by tumor antigens, mobilized to tumors in tumor-bearing individuals; the findings of that report suggested that TILs are the ideal carriers for therapeutic genes. ${ }^{11}$ Similar characteristics of activated $\mathrm{T}$ lymphocytes may be expected in cases of autoimmune diseases as well as organ transplantation; however, related investigations have been rare in the last decade, and efficient gene transfer vectors to activated $\mathrm{T}$ cells left much to be desired.

Recently, much attention has been directed to a new gene transfer vehicle for $\mathrm{T}$ lymphocytes, namely, human immunodeficiency virus (HIV)-based lentiviral vector, as a CD4-lymphocyte-directed tropism of HIV. Current efforts dramatically enhanced gene transfer efficiency to activated $\mathrm{T}$ cells (mean $=51 \%$ versus $15 \%$ in the conventional HIV vector) by constructing a central deoxyribonucleic acid (DNA) flap that facilitated nuclear import and chromosomal integration of the vector genome. ${ }^{12}$ However, potential safety concerns, based on pathogenic viruses including HIV, slowed the application for clinical use. $^{13}$ 
We recently developed a unique vector based on the Sendai virus (SeV), which is not been known to be a pathogenic virus in humans. ${ }^{14,15,18} \mathrm{SeV}$ attaches to host cells due to interactions between its hemagglutininneuramidase (HN) of $\mathrm{SeV}$ and sialic acid residues on surface glycoproteins of host cells. Afterward, the virus fuses into host cells using activated fusion protein (F1), which is formed by cleavage of an inactive precursor fusion protein (F0) with proteolytic enzyme. ${ }^{14}$ For example, in vivo, F0 is cleaved into F1 by tryptase Clara in the lower airway, which is a determinant of organ tropism. ${ }^{15} \mathrm{SeV}$ is a minus strand RNA virus, and the mRNA is transcribed by virusderived RNA polymerase, large (L)/phosphatase (P) protein complex; the viral proteins are produced from transcribed RNA. The transcription of the mRNA is rapidly initiated when the Sendai virus fuse into host cells expressing the virus-receptor for $\mathrm{HN}$ and also the recently suggested coreceptor for $\mathrm{F}$ protein. ${ }^{14,16,17}$ However, the transcription is affected by the kinase activity of host cells. ${ }^{14}$ Finally, the viral progenies are released from host cells without cellular damage by a budding process. The neuraminidase activity of $\mathrm{HN}$, which dissociates sialic acid residues from the surface of host cells, is an important activity for the detachment of the virus. ${ }^{14}$

Using this vector, we demonstrated markedly superior gene transfer efficiency compared to findings with currently available vectors for use in various organs. ${ }^{19-25}$ In contrast to systems involving retroviridae, replication and transcription of $\mathrm{SeV}$ are seen in the cytoplasm accompanying cellular tubulin, ${ }^{26}$ and nuclear import and genomic integration are not required, ${ }^{14}$ thereby suggesting the elimination of potential risks, including unexpected events related to chromosomal injury.

We report here that $\mathrm{SeV}$ efficiently transduced a reporter gene, jellyfish enhanced green fluorescent protein (EGFP), into murine and human activated $\mathrm{T}$ cells ex vivo using a simple transduction technique. We also found that SeV-mediated gene transfer was highly selective for antigen-specific activated $\mathrm{T}$ cells, whereas antigen-irrelevant $\mathrm{T}$ cells were rarely transduced. A possible mechanism of activated T-lymphocyte-specific transduction is also discussed.

\section{Results}

Recombinant SeV is a highly efficient vehicle for gene transfer into activated $T$ cells

We first investigated gene transfer efficiency into $T$ cells using SeV expressing EGFP gene (SeV-EGFP). Murine lymphocytes were cultured with SeV-EGFP (Multiplicity of infection $(\mathrm{MOI})=62.5)$ for $48 \mathrm{~h}$. While unstimulated murine CD4 or CD8 T cells hardly expressed EGFP (range $0.5-1.5 \%$ or $0.8-2.0 \%$, respectively), anti-mouse CD3 and anti-mouse CD28 monoclonal antibody (mAb)activated CD4 or CD8 T cells expressed a high intensity of EGFP and the percentages of EGFP-positive cells dramatically increased (range $65-85 \%$ or $70-92 \%$, respectively) (Figure 1a). In both activated CD4 and CD8 T cells, SeV-EGFP exhibited dose-dependent EGFP expression and the percentage of EGFP-positive cells nearly reached a plateau level at an MOI of 12.5 with $\mathrm{SeV}$ (data not shown). $\begin{array}{ccc}\text { a } & \text { Ab } & \text { Ab } \\ \text { stimulation } & \text { stimulation } & \text { stimulation } \\ \mathrm{SeV}+ & \mathrm{SeV}+ & \mathrm{SeV}-\end{array}$

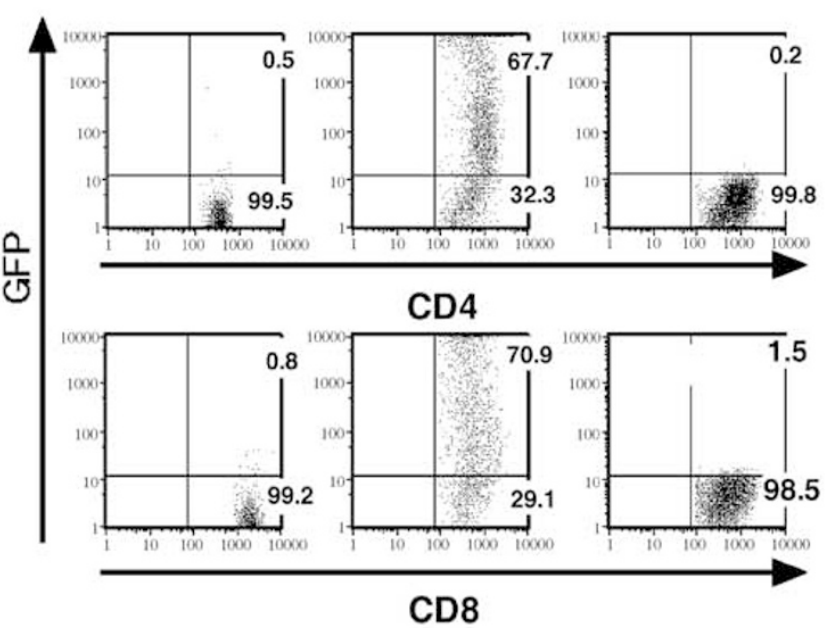

b

viable $\mathrm{CD}^{+}$-gated

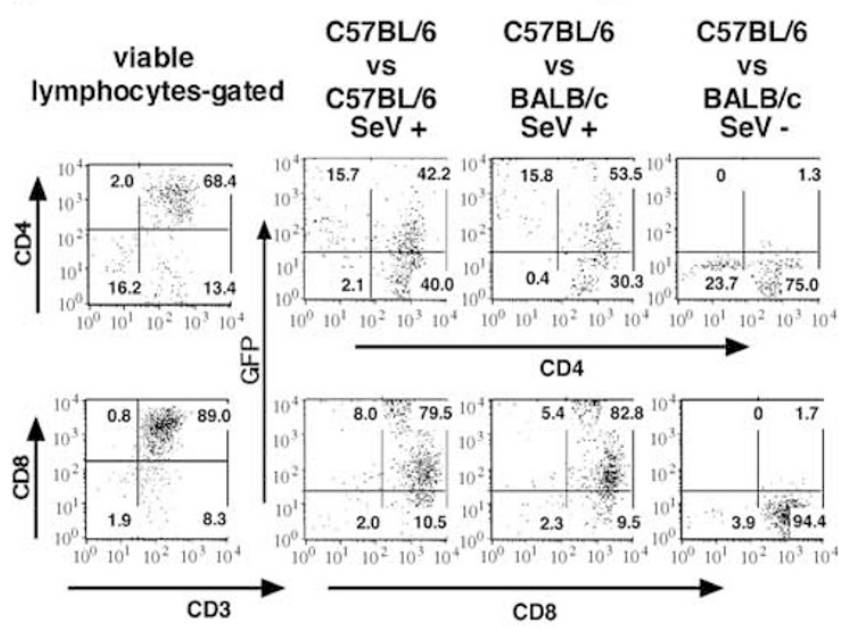

c

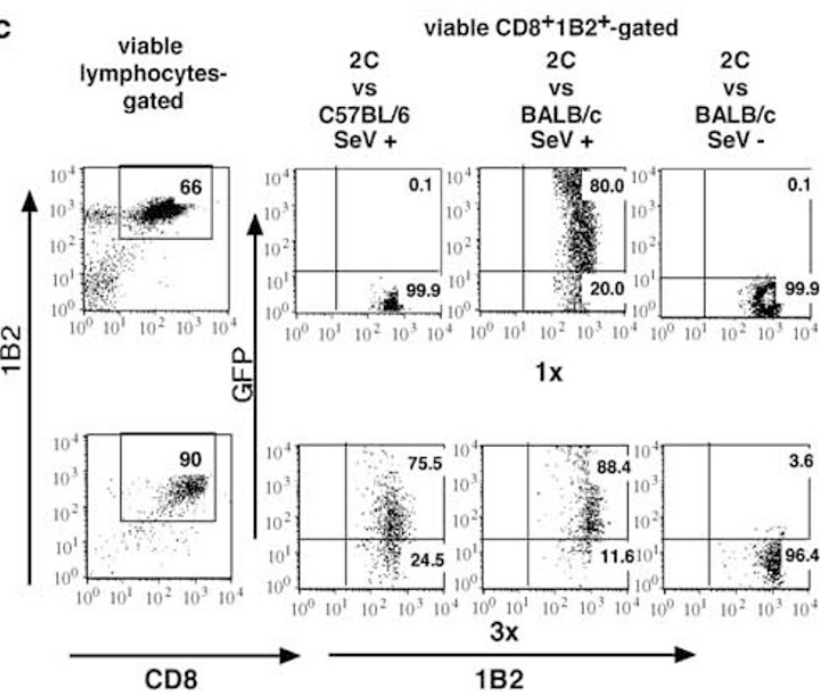


Next, we determined if $\mathrm{SeV}$ could transduce EGFP in antigen-activated T cell lines. Both CD4 and CD8 T cell lines highly expressed the transduced EGFP, regardless of the absence of an allogenic stimulator, although a higher expression level and a higher positive population were obtained in the case of the allogenic stimulator than in the case of syngenic irradiated cells (Figure 1b). In addition, the EGFP expression level and the percentage of positive cells were slightly lower in the CD4 T cell line than in the CD8 $\mathrm{T}$ cell line (Figure $1 \mathrm{~b}$ ). Taken together, these findings suggest that $\mathrm{SeV}$ can transfer foreign genes into activated $\mathrm{T}$ cells but not into naive ones.

To confirm these observations, ie, that $\mathrm{SeV}$ could transduce antigen-activated $\mathrm{T}$ cells, we used $\mathrm{T}$ cells from 2C transgenic mice $(2 \mathrm{C}-\mathrm{Tg})$, which were $\mathrm{L}^{\mathrm{d}}$ (a class I major histocompatibility (MHC) antigen)-reactive T-cell receptor (TCR) transgenic mice ${ }^{27}$ and had numerous naive clonal $\mathrm{T}$ cells (2C-Tg $\mathrm{T}$ cells). While SeV-EGFP hardly transduced EGFP into naive $2 \mathrm{C}-\mathrm{Tg}\left(\mathrm{H}-2^{\mathrm{b}}\right.$; $\left.\mathrm{K}^{\mathrm{b}}, \mathrm{D}^{\mathrm{b}}, \mathrm{L}^{-}\right) \mathrm{T}$ cells, which were cultivated with the syngenic $\mathrm{C} 57 \mathrm{BL} / 6$ stimulator $\left(\mathrm{H}-2^{\mathrm{b}} ; \mathrm{K}^{\mathrm{b}}, \mathrm{D}^{\mathrm{b}}, \mathrm{L}^{-}\right)$, SeVEGFP efficiently transduced EGFP into activated 2C-Tg $\mathrm{T}$ cells, which were cultivated with BALB/c $\left(\mathrm{H}-2^{\mathrm{d}}\right.$; $\left.\mathrm{K}^{\mathrm{d}}, \mathrm{D}^{\mathrm{d}}, \mathrm{L}^{\mathrm{d}}\right)$ stimulator. Furthermore, SeV-EGFP efficiently transduced EGFP to preactivated $2 \mathrm{C}-\mathrm{Tg} \mathrm{T}$ cell line in the presence of either allogenic or syngenic stimulators (Figure 1c). It was noted that incubation of these $\mathrm{T}$ cell lines with $\mathrm{SeV}$ for only $30 \mathrm{~min}$ at $37^{\circ} \mathrm{C}$ led to a maximum expression of EGFP (data not shown). These findings indicate that $\mathrm{SeV}$ is able to transduce a target gene into

Figure 1 Transduction efficiency by SeV into murine $T$ cells. (a) Transduction efficiency in activated or naive $T$ cells. After murine lymphocytes had been cultured with or without SeV-EGFP for 2 days, the cells were collected and stained with APC-conjugated anti-CD3 and PEconjugated anti-CD4 (top panel) or CD8 (bottom panel) antibodies. Dot plots show the expression of CD4 or CD8 and EGFP among viable $\mathrm{CD}^{+} \mathrm{CD}^{+}$or $\mathrm{CD}^{+} \mathrm{CD}^{+}$lymphocytes, respectively. Transduction efficiency is indicated as the percentage of EGFP-positive cells at the upper right corner in each quadrant. Left panel: the cells were cultured in non-Ab-coated wells. Middle panel: the cells were cultured in anti-mouse CD3 and anti-mouse CD28 mAb-coated wells. Right panel: the cells were cultured in anti-mouse CD3 and anti-mouse CD28 mAb-coated wells without SeV-EGFP. As a negative control, similar data were obtained from cells cultured with SeV-luci. Reproductive data were obtained from more than four independent experiments. (b) Transduction efficiency into T cell lines. After T cell lines had been cultivated with or without SeV-EGFP for 2 days, the collected CD4 (top panel) or CD8 (bottom panel) T cells were analyzed, as described in (a). In the panel at the far left, the dot plots show the expression of $C D 3$ and $C D 4$ or $C D 8$ among the viable lymphocytes. The number indicates the percentage of each quadrant. Otherwise, the dot plots show the EGFP expression of CD4 or CD8 Tcells among CD $3^{+}$-gated viable lymphocytes. Second panel: the cells were cultured with irradiated C57BL/6 stimulator. Third panel: the cells were cultured with irradiated $B A L B / c$ simulator. Right panel: the cells were cultured with irradiated $B A L B / c$ simulator without SeV-EGFP. Reproductive data were obtained from more than four independent experiments. (c) Transduction efficiency in alloantigen-specific activation of naive $T$ cells and $T$ cell lines. After naive (top panel: ' $1 \times$ ') $2 \mathrm{C}$-Tg lymphocytes or $2 \mathrm{C}-\mathrm{Tg} \mathrm{T}$ cell lines (bottom panel: ' $3 \times$ ') had been cultured with or without SeV-EGFP for 2 days, the cells were collected and stained with APC-conjugated anti-CD8 and biotin-conjugated anti-clonotypic T-cell receptor $m A b$ (1B2) followed by $P E$-streptoavidin. In the panel at the left, the percentage of $C D 8^{+} 1 B 2^{+} T$ cells among viable lymphocytes is indicated. Otherwise, the dot plots show the EGFP expression of viable clonotypic T cells. Second panel: the cells were cultured with an irradiated B6 stimulator. Third panel: the cells were cultured with an irradiated $B A L B / c$ simulator. Right panel: the cells were cultured with an irradiated $B A L B / c$ simulator, without SeV-EGFP. Reproductive data were obtained from two independent experiments. murine $\mathrm{T}$ cells using a simple transducing procedure, when the T cells are in an antigen-activated state.

Since $\mathrm{T}$ cells irrelevant to a target antigen may also have been activated by the bystander effect of a strong alloresponse in vitro, it is possible that the irrelevant $\mathrm{T}$ cells were transduced. To verify that this vigorous transduction by $\mathrm{SeV}$ was restricted to antigen-specific activated $\mathrm{T}$ cells, we performed the following experiments. We used naive $2 \mathrm{C}-\mathrm{Tg} \mathrm{T}$ cells as antigen-specific $\mathrm{T}$ cells that did not respond to $\mathrm{C} 3 \mathrm{H}\left(\mathrm{H}-2^{\mathrm{k}} ; \mathrm{K}^{\mathrm{k}}, \mathrm{D}^{\mathrm{k}}, \mathrm{L}^{-}\right)$ stimulator but did respond to a BALB/c stimulator. In the culture system described under Materials and methods, we were able to determine whether or not SeV-EGFP transduced EGFP into 2C-Tg T cells which were not activated by an alloantigen, but might have been affected by the alloresponse of T cells from C57BL/ 6 mice to the $\mathrm{C} 3 \mathrm{H}$ stimulator in a mixed lymphocyte culture (MLC). With $\mathrm{C} 3 \mathrm{H}$ stimulator cells, EGFPpositive $2 \mathrm{C}-\mathrm{Tg} \mathrm{T}$ cells were rare, even in cases involving the allogenic response of C57BL/6 T cells against $\mathrm{C} 3 \mathrm{H}$ stimulator cells; this finding was similar to findings with the use of C57BL/6 syngenic stimulator cells or no stimulator cells (Figure 2). In the case of BALB/C stimulator cells, the $2 \mathrm{C}-\mathrm{Tg} \mathrm{T}$ cells vigorously expressed EGFP (Figure 2). These findings indicate that SeVmediated gene transfer was restricted to specific antigen-activated T cells.

\section{Duration of transgene expression by $\mathrm{SeV}$ in activated $T$ cells}

Next, we examined the maintenance of the transduced gene in vitro. After cultivation of activated $2 \mathrm{C}-\mathrm{Tg} \mathrm{T}$ cells with the vector, the transduced $\mathrm{T}$ cells were maintained in vitro. The EGFP expression was maintained for at least 20 days but the expression level rapidly decreased following a peak expression observed at $48 \mathrm{~h}$ (Figure 3).

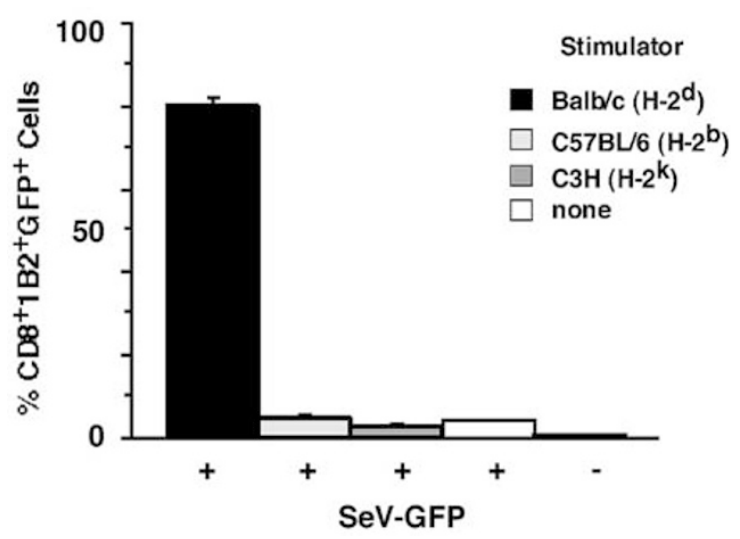

Figure 2 Effect of bystander activation in transduction by SeV. 2C-Tgnaive lymphocytes and $C 57 B L / 6$-naive lymphocytes were stimulated with irradiated $B A L B / c$ (black bar), $C 57 B L / 6$ (gray bar), or $C 3 H$ (check bar) lymphocytes or with no lymphocytes (white bar) with (+ of X-axis) or without (- of X-axis) SeV-EGFP for 2 days. The percentage of EGFPpositive cells was obtained from viable $C D 8^{+} 1 B 2^{+} T$ cells. The Y-axis indicates the percentage of EGFP-positive clonotypic cells. Individual data are indicated as mean percentage \pm standard error of the means (s.e.m.) of triplicate wells $(\mathrm{n}=3)$, and similar results were observed in two separate experiments. There was statistical significance $(\mathrm{P}<0.01)$ between $2 \mathrm{C}-\mathrm{Tg} T$ cells stimulated with $\mathrm{C} 3 \mathrm{H}$ and with $\mathrm{BALB} / \mathrm{c}$, but not between $2 \mathrm{C}-\mathrm{Tg} \mathrm{T}$ cells stimulated with $\mathrm{C} 3 \mathrm{H}$ and with $\mathrm{C} 57 \mathrm{BL} / 6$. The statistical significance was determined using Fisher's PLSD test. 


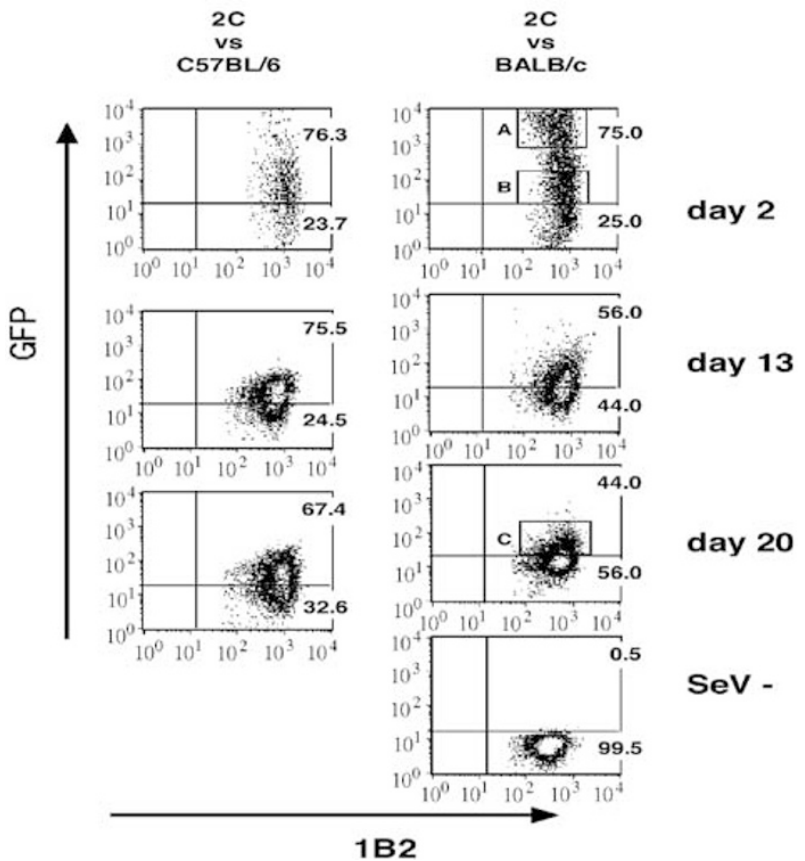

Figure 3 Maintenance of EGFP expression in T cells transduced by SeV. After $T$ cell lines from $2 \mathrm{C}-\mathrm{Tg}$ mice had been stimulated with irradiated lymphocytes from $C 57 B L / 6$ (left column) or $B A L B / c$ (right column) mice with SeV-EGFP for 6 days, the transduced T cells were maintained by weekly restimulation of irradiated $\mathrm{C} 57 \mathrm{BL} / 6$ or $\mathrm{BALB} / \mathrm{c}$ without SeV. Dot plots show the expression of EGFP among viable clonotypic T cells. The number in the upper right corner of quadrants indicates the percentage of EGFP-positive or -negative clonotypic T cells at day 2 (top panel), day 13 (second panel from the top), and day 20 (third panel from the top). As a negative control, the data from the noninfected $2 \mathrm{C}-\mathrm{Tg} \mathrm{T}$ cell line that had been stimulated for 20 days are indicated (bottom panel). These data are representative of two separate experiments. The gates indicated in the panels of the dot plots were used for cell sorting in order to assess the number of SeV genome copies in the transduced $2 \mathrm{C}-\mathrm{Tg}$ T cells by real-time PCR (A: EGFP-high population on day 2, b: EGFP-low population on day 2, c: EGFP-low population on day 20).

The EGFP expression level was not elevated, even with the restimulation of transduced T cells, using the BALB/c stimulator. These findings were also observed in the allospecific activated $\mathrm{T}$ cell line (data not shown). Furthermore, we confirmed that the expression levels of EGFP were correlated to the number of copies of the genome of $\mathrm{SeV}$ in the transduced $\mathrm{T}$ cells. On day 2, the number of genome copies was approximately 250 copies per cell in an EGFP-high population (Figure 3, gate A) and five per cell in an EGFP-low population (Figure 3, gate B). On day 20, the genome copy was six per cell, which was similar to that observed in the EGFP-low population on day 2 (Figure 3, gate C).

\section{Gene transfer to activated human $T$ cells and a $T$ cell line}

Freshly isolated human peripheral blood lymphocytes (PBL) from healthy donors were cultured with $2.5 \times 10^{7}$ plaque forming unit (PFU) of SeV-EGFP $(\mathrm{MOI}=30)$ for $48 \mathrm{~h}$. In contrast to that observed in mouse $\mathrm{T}$ cells, relatively higher EGFP-positive ratios were obtained in the cases of unstimulated human CD4 (mean $=23.1 \%$; range $15-45 \%$ ) or CD8 T cells (mean $=34.0 \%$; range 18 $50 \%$ ), although the intensities of EGFP expression were relatively low (Figure 4a).
We considered that the population of activated/ memory T cells might be higher in human PBL than that in murine lymphoid tissue from mice that had been maintained under specific-pathogen-free conditions. Discrimination between naive $\mathrm{T}$ cells $\left(\mathrm{CD} 45 \mathrm{RA}^{+} \mathrm{CD} 62 \mathrm{~L}^{+}\right)$ and activated/memory $\mathrm{T}$ cells was undertaken, and we analyzed the EGFP expression of each T-cell population. As expected, the percentage of EGFP-positive activated/ memory $\mathrm{T}$ cells was far higher than that in naive T cells, with the EGFP-positive cells below 4\% (Figure $4 \mathrm{~b}$ ). On the other hand, anti-human CD3 and anti-human CD28 mAb-activated human CD4 or CD8 T cells expressed high intensities of EGFP and the positive cell rates were high (CD4: range $30-69 \%$ or CD8: $50-70 \%$ ) (Figure 4a). In a human alloantigen-stimulated T cell line, higher percentages of EGFP-positive CD4 or CD8 T cells were observed (97 or 98\%) than those noted in antihuman CD3 and anti-human CD28 mAb-activated T cells (Figure 4c). In addition, as seen in murine $\mathrm{T}$ cell lines, simple incubation of the $\mathrm{T}$ cell line with $\mathrm{SeV}$ for only $30 \mathrm{~min}$ at $37^{\circ} \mathrm{C}$ led to a near maximum expression of EGFP (Figure 4d).

\section{Entry of the SeV vector, after cell surface attachment,} occurs in activated but not naive $T$ cells

The following factors may have led to the observed difference in transduction efficiency between naive and activated T cells: (i) a difference in the expression of a specific receptor for $\mathrm{SeV}^{28}$ (ii) a difference in the expression of a putative coreceptor for membrane fusion, ${ }^{16,17}$ (iii) a difference in the intracellular signal induced by T-cell activation, which could have affected the transcription of $\mathrm{SeV}$ after entry. ${ }^{15}$ To explore these factors, we performed the following experiments using murine $\mathrm{T}$ cells, the experiments in which it was not necessary to separate naive $\mathrm{T}$ cells from activated/ memory T cells.

Freshly isolated lymphocytes were mixed with or without ultra violet (UV)-inactivated SeV expressing the firefly luciferase gene (SeV-luci), which retained the receptor-binding capacity and neuraminidase activity of HN but was replication-incompetent, in order to interfere with the specific receptor for $\mathrm{SeV}$ on $\mathrm{T}$ cells or to dissociate sialic acid residues from receptors on T cells. ${ }^{20}$ Afterward, the T cells were incubated with SeV-EGFP $(\mathrm{MOI}=62.5)$ for $30 \mathrm{~min}$ at $37^{\circ} \mathrm{C}$ and were vigorously washed in order to prevent the contamination of SeVEGFP in subsequent cultures. After the $\mathrm{T}$ cells were cultivated in anti-mouse CD3 and anti-mouse CD28 mAb-coated wells (activating wells) without vector for 2 days, the expression of EGFP was examined. While the percentage of EGFP-positive CD4 and CD8 T cells was 35 and $50 \%$ in the $T$ cells that had not been treated with UV-inactivated SeV-luci (UV-SeV) (Figure $5 \mathrm{a})$, the transduction of EGFP was almost completely prevented by pretreatment with UV-SeV in both CD4 and CD8 T cells (Figure 5a). The prevention was unlikely a result of a decrease in the viability of $\mathrm{T}$ cells by pretreatment with UV-SeV, since most pretreated lymphocytes were able to express the EGFP when the pretreated cells had been cocultured with fresh $\mathrm{SeV}$ EGFP in activating wells (Figure 5a). It was not surprising that the UV-SeV-pretreated T cells, from which the sialic acid residues had been dissociated, would be 
a

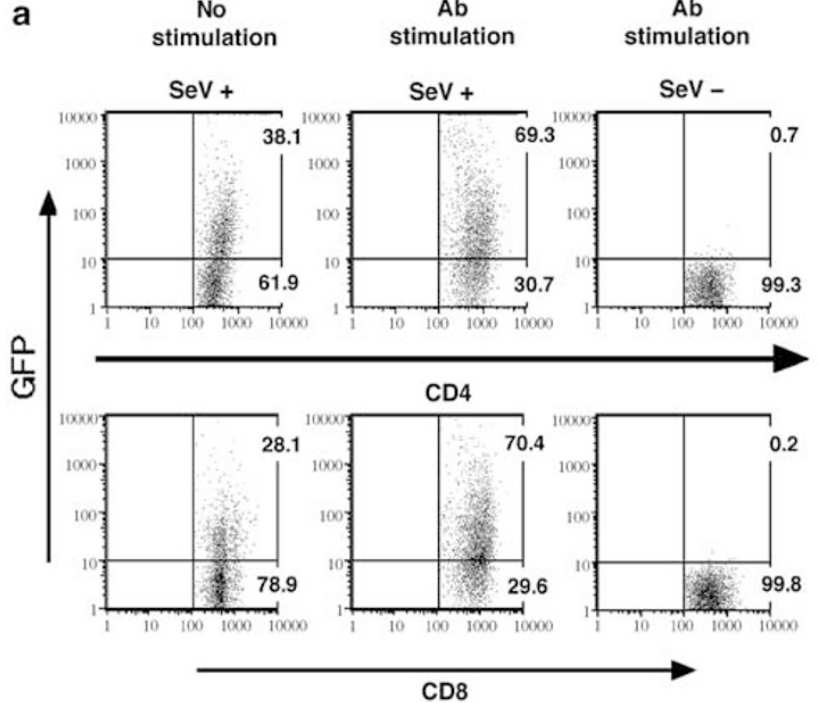

c

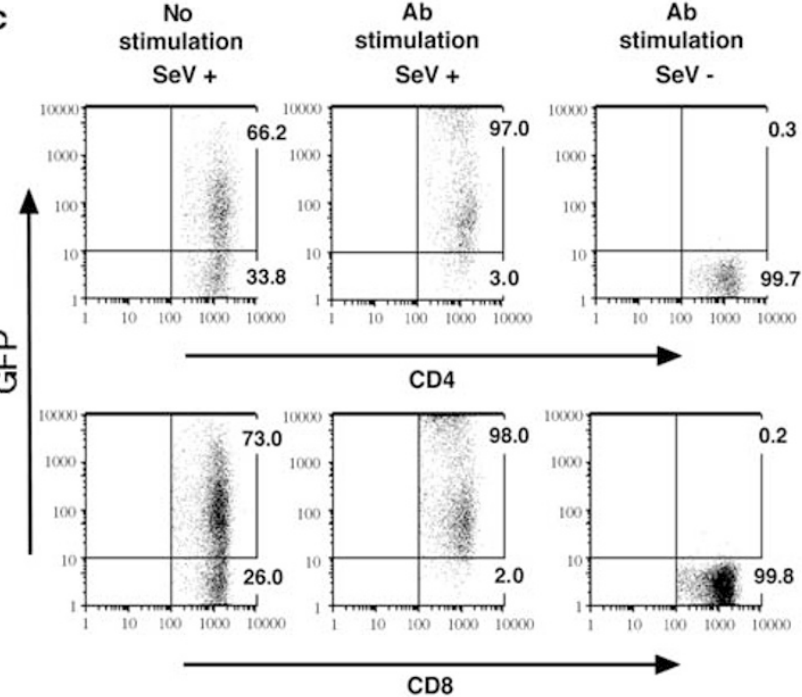

b
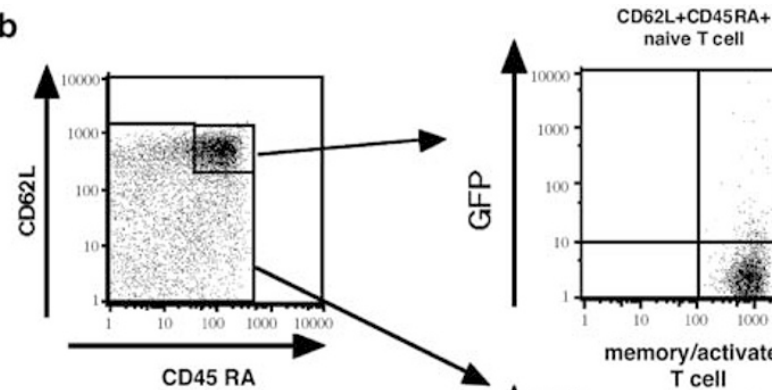

$\frac{0}{0}$

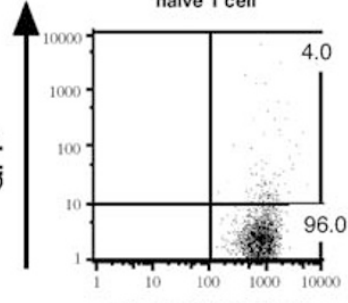

memory/activated

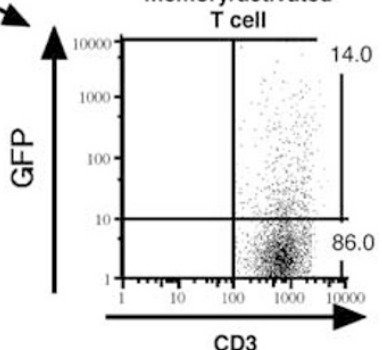

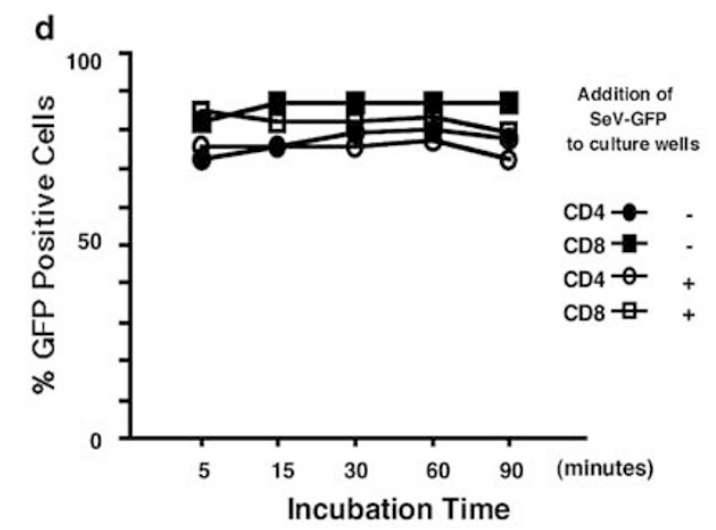

Figure 4 Transduction efficiency by SeV into human T cells. (a) Transduction efficiency in Ab-stimulated or nonstimulated T cells. Human lymphocytes were cultivated with or without SeV-EGFP for 2 days and were stained with APC-conjugated anti-CD3 and PE-conjugated anti-CD4 (top panel) or CD8 (bottom panel) antibodies. Dot plots show the expression of CD4 or CD8 and EGFP among viable CD4 or CD8 T cells, respectively. Left panel: the cells were cultured in non-Ab-coated wells. Middle panel: the cells were cultured in anti-human CD3 and anti-human CD28 mAb-coated wells. Right panel: the cells were cultured in anti-human CD3 and anti-human CD28 mAb-coated wells without SeV-EGFP. As a negative control, similar data were obtained from cells cultured with SeV-luci. Reproductive data were obtained from more than four independent experiments. (b) Transduction efficiency in naive or memory/activated T cells. Freshly isolated T cells cultured with SeV-EGFP in non-Ab-coated wells for 2 days were stained with APC-conjugated antiCD62L, PE-conjugated anti-CD3, and biotinylated anti-CD45RA antibodies, followed by staining with streptavidin PerCP. In the left panel, the dot plot shows the expression of $C D 62 L$ and CD45RA among CD3 ${ }^{+} T$ cells. In the right panel, the dot plot shows the expression of CD3 and EGFP among CD62L high and CD45RA ${ }^{\text {high }} T$ cells; the cells were naive T cells (upper right panel) or other cells, that is, memory/activated T cells (lower right panel). Reproductive data were obtained from three experiments using samples from individual, healthy donors. (c) Transduction efficiency in a human T cell line. After this human T cell line had been cultivated with or without SeV-EGFP, the collected CD4 (top panel) or CD8 (bottom panel) T cells were analyzed as described in (a). Left panel: the cells were cultured in non-Ab-coated wells. Middle panel: the cells were cultured in anti-human CD3 and anti-human CD28 mAb-coated wells. Right panel: the cells were cultured in anti-human CD3 and anti-human CD28 mAb-coated wells, without SeV-EGFP. (D) Incubation time for transduction in human T cell lines. After this human T cell line had been incubated with SeV-EGFP for 5, 15, 30, 60, and 90 min at $37^{\circ} \mathrm{C}$, the cells were vigorously washed and cultured in anti-mouse CD3 and anti-mouse CD28 mAb-coated wells for 2 days. The collected cells were stained as described in (a) (CD4 T cells: closed circles, CD8 T cells: closed squares). As a positive control, the pretreated cells were cultured with SeV-EGFP (CD4: open circles, CD8: open squares) for two days. Reproductive data were obtained from 2 independent experiments using T cell lines from two individual healthy donors.

infected by SeV-EGFP during the culture periods, because it was assumed that the UV-SeV-pretreated $\mathrm{T}$ cells regained the specific receptor for $\mathrm{SeV}$ on $\mathrm{T}$ cells. ${ }^{28}$ These findings suggest that the receptor of $\mathrm{SeV}$ might be expressed on the naive $\mathrm{T}$ cells.
Based on the features of the life cycle of the Sendai virus and a previous report, in which murine and human lymphocytes aggregated by Sendai virus at $4^{\circ} \mathrm{C}$ but did not fuse after incubation at $37^{\circ} \mathrm{C},{ }^{29}$ we hypothesized that $\mathrm{SeV}$ could attach to naive $\mathrm{T}$ cells but could not be 

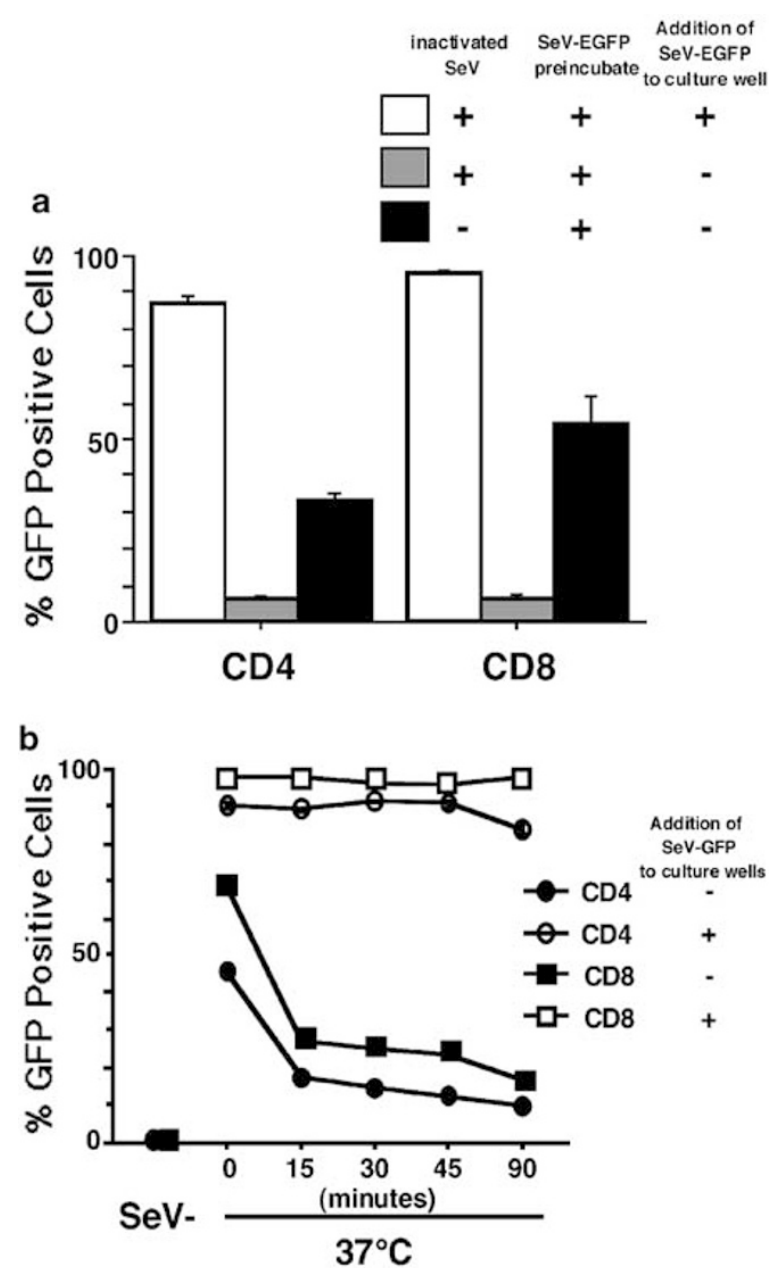

Figure 5 Assessment of entry of $\mathrm{SeV}$ into naive or activated $\mathrm{T}$ cells. (a) After C57BL/6 lymphocytes pretreated with (white and gray bars) or without (black bars) UV-inactivated SeV-luci were incubated with SeV$E G F P$, the lymphocytes were cultured in anti-mouse CD3 and anti-mouse CD28 mAb-coated wells for 2 days without SeV-EGFP. As a positive control, the pretreated cells were cultured with SeV-EGFP in anti-mouse CD3 and anti-mouse CD28 mAb-coated wells for 2 days (white bars). The collected cells were analyzed as described in Figure 1a. The Y-axis indicates the percentage of EGFP-positive CD4 (left three bars) or CD8 (right three bars) $T$ cells. Individual data are indicated as the mean percentage \pm s.e.m. of triplicate wells $(\mathrm{n}=3)$. There was statistical significance $(\mathrm{P}<0.01)$ in each group, as determined using Fisher's PLSD test. (b) After naive C57BL/6 lymphocytes had been incubated without (scale at far left of the $\mathrm{X}$-axis) or with (other $\mathrm{X}$-axis scales) SeV-EGFP for 30 min at $4^{\circ} \mathrm{C}$, the cells were vigorously washed and incubated at $37^{\circ} \mathrm{C}$ without SeV for $0,15,30$, 45, and 90 min. After the cells had been cultured in anti-mouse CD3 and anti-mouse CD28 mAb-coated wells for 2 days, the collected cells were stained as described in (a) (CD4 T cells: closed circles, CD8 T cells: closed squares). As a positive control, the pretreated cells were cultured with $\mathrm{SeV}$ EGFP (CD4: open circles, CD8: open squares). The values are indicated as the mean percentage \pm s.e.m. of triplicate wells $(\mathrm{n}=3)$. In both $\mathrm{CD} 4$ and CD8 $T$ cells, there was statistical significance $(\mathrm{P}<0.01)$ between incubation for $0 \mathrm{~min}$ at $37^{\circ} \mathrm{C}$ and incubation for $15 \mathrm{~min}$. Furthermore, there was statistical significance $(\mathrm{P}<0.01)$ between incubation for 15 min at $37^{\circ} \mathrm{C}$ and incubation for $90 \mathrm{~min}$. The statistical significance was determined using Fisher's PLSD test.

internalized to the cytoplasm because of a defect in a putative coreceptor. ${ }^{16,17}$ Therefore, $\mathrm{SeV}$ might detach from naive $T$ cells by its own neuraminidase activity of $\mathrm{HN}$. To prove this hypothesis, the following experiments were conducted. After freshly isolated lymphocytes had been incubated with SeV-EGFP $(\mathrm{MOI}=100)$ at $4^{\circ} \mathrm{C}$ (the temperature at which the neuraminidase of $\mathrm{HN}$ and $\mathrm{F} 1$ protein functioned poorly, but at which $\mathrm{SeV}$ was able to attach to host cells owing to the interactions between sialic acid residues on $\mathrm{T}$ cells and $\mathrm{HN}$ of $\mathrm{SeV}$ ), the lymphocytes were incubated in fresh medium for various periods of time at $37^{\circ} \mathrm{C}$ (the temperature at which neuraminidase and F1 protein functioned well). Thereafter, the T cells were vigorously washed in order to prevent the contamination of SeV-EGFP in subsequent cultures. After the T cells were cultivated in activating wells without vector for 2 days, the expression of EGFP was examined. Since all of the T cells were uniformly activated, the EGFP expression of T cells was affected by factors related to entry, and not by factors related to $\mathrm{SeV}$ gene expression, eg, cellular kinase activity. When the $\mathrm{T}$ cells were immediately activated after incubation at $4^{\circ} \mathrm{C}$, the percentage of EGFP-positive CD4 and CD8 T cells was approximately 50 and $70 \%$. On the other hand, when, before activation, the naive $\mathrm{T}$ cells were incubated for various periods of time at $37^{\circ} \mathrm{C}$ following incubation at $4{ }^{\circ} \mathrm{C}$, the percentage of EGFP-positive T cells decreased in a time-dependent manner (Figure 5b). Incubation for $90 \mathrm{~min}$ at $37^{\circ} \mathrm{C}$ resulted in the lowest percentage of EGFP-positive T cells; this finding was somewhat similar to that obtained with freshly isolated $\mathrm{T}$ cells that had been cultured in activating wells with residual SeV-EGFP in final washing medium after incubation at $37^{\circ} \mathrm{C}$ (data not shown). The pretreatment with $\mathrm{SeV}$ did not result in a decrease in the viability of the T cells, because all T cells that had been pretreated with SeV-EGFP and thereafter incubated in fresh medium for various periods of time, followed by coculture with fresh SeV-EGFP for 2 days in activating wells, were able to express EGFP at high percentages (Figure $5 b$ ). Furthermore, when activated T cell lines were used, the T cells pretreated with SeV-EGFP at $4{ }^{\circ} \mathrm{C}$ and thereafter incubated in fresh medium for 30 or $90 \mathrm{~min}$, followed by cultivation without SeV-EGFP for 2 days in activating wells, were able to express EGFP at high percentages (data not shown). It is highly unlikely that the introduced $\mathrm{SeV}$ was released from the naive $\mathrm{T}$ cells. Therefore, these findings suggest that the $\mathrm{SeV}$ attached itself to the naive $T$ cells, but that it did not fuse to them. Moreover, the findings indicated that $\mathrm{SeV}$ did enter the activated $\mathrm{T}$ cells.

\section{Discussion}

In the current study, we clearly demonstrated that the $\mathrm{SeV}$ vector was able to efficiently express a foreign gene in activated murine and human T cells, but not in naive $\mathrm{T}$ cells. This effect can be explained based on the specific internalization of vector particles into the activated $\mathrm{T}$ lymphocytes, but not into naive T cells. The current study thus suggests that $\mathrm{SeV}$ may be an important alternative for T-cell-directed gene transfer in the treatment of immunological diseases.

A highly efficient and simple gene transfer system would be important for realizing T-cell-targeted gene transfer, particularly from the point of view of the clinical setting, since a large number of viable antigen-specific $T$ cells is necessary to obtain an effective clinical outcome with a wide range of immunological diseases. As previously reported, in the systems of retrovirus- and 
lentivirus-mediated gene transfer to $\mathrm{T}$ cells, the vectors should be concentrated by centrifugation for optimal gene transfer with or without additional reagents. ${ }^{5-8,30-33}$ However, in our systems, excellent gene transfer could be achieved by the simple addition of $\mathrm{SeV}$ vector solution without specific reagents or centrifugation. Moreover, optimal SeV-mediated gene transfer to activated $\mathrm{T}$ cells could be performed during a relatively brief exposure time (less than $30 \mathrm{~min}$, Figure $4 \mathrm{~d}$ ), with representative results seen in nasal mucosa, ${ }^{20}$ in the vasculature, ${ }^{21}$ in retinal tissue, ${ }^{24}$ as well as in human umbilical cord bloodderived CD34-positive cells. ${ }^{45}$ In addition, rare syncytium formation and few cytopathic effects were observed at the MOI used in this study (data not shown). Furthermore, changes in the number of activated T cells that were cocultured with SeV-EGFP were comparable to those observed in activated T cells cultured without $\mathrm{SeV}$ (data not shown). In the clinical setting, these characteristics of SeV-mediated gene transfer may simplify the ex vivo gene modification strategy using $\mathrm{T}$ lymphocytes, and may also minimize the procedure-dependent loss of cellular viability.

One issue raised by the present study using antibodyactivated human $\mathrm{T}$ cells was that the EGFP-positive cell ratio varied among individual donors, whereas murine T-cell gene transfer generally showed stable gene transfer efficiency. We also found that a lower cellular concentration of human lymphocytes in vitro led to a lower EGFPpositive cell ratio, a result that was also seen in murine cells (data not shown). These findings suggest that other costimulatory stimuli (eg, 4-1BB), which are provided by antigen-presenting cells among bulk lymphocyte populations under anti-CD3 and anti-CD28 mAb activation, ${ }^{34}$ may be necessary to transfer the EGFP gene by $\mathrm{SeV}$. Actually, an allogenic lymphocyte-activated human T cell line vigorously expressed EGFP in the presence of SeV. We are currently assessing which costimulatory factors are required for stable and efficient gene transduction to T cells.

Regarding the possible mechanism of activated T-cellspecific gene transfer, our findings suggest that although $\mathrm{SeV}$ might attach itself to naive T cells, it does not enter the cytoplasm of these cells. Using naive lymphocytes, Okada and co-workers demonstrated a titer-dependent cellular aggregation at $4^{\circ} \mathrm{C}$ with $\mathrm{SeV}$, whereas cell fusion was not observed at $37^{\circ} \mathrm{C} .{ }^{29}$ It is of note that their findings are compatible to the current results.

As regards clinical applications, one disadvantage of $\mathrm{SeV}$ might be the observed rapid decrease in transgene expression among activated T cells, even though in the present study a decrease in the level of expression continued for over 3 weeks. The results of the real-time polymerase chain reaction (PCR) conducted here revealed that the EGFP expression levels were correlated with the number of $\mathrm{SeV}$ genome copies in the T cells. This finding suggests that the rapid decrease in transgene expression was because of the rapid clearance of the $\mathrm{SeV}$ genome among the activated T cells. The mechanism of rapid decrease in gene expression with $\mathrm{SeV}$ is still unclear. This result is in conflict with our previous findings that indicated stable transgene expression using vascular smooth muscle cells in vitro. ${ }^{21}$ This discrepancy is unlikely a result of the loss of T-cell activation signals, since restimulation of transduced $\mathrm{T}$ cells did not increase EGFP expression. In general, virally transduced genes are modulated, or a viral genome is cleared by hostderived factors, including interferons (IFNs). ${ }^{35}$ Thus, a possible explanation for the observed discrepancy would be that IFNs, especially IFN-gamma, may affect the transcription of $\mathrm{SeV}$, because IFNs were more vigorously produced by an allogenic antigen-stimulated $\mathrm{T}$ cell line than by a nonhematopoietic cell line. ${ }^{36}$ Indeed, alloreactive $\mathrm{T}$ cell lines from IFN-gamma receptor-deficient mice maintained a high expression of EGFP for over 3 weeks, in contrast to rapid decrease of the EGFP expression in alloreactive $\mathrm{T}$ cell lines from wild-type mice (unpublished observation). Therefore, if a high level of target gene expression is required in a T-cell-directed gene therapy using $\mathrm{SeV}$, it may be necessary to regulate the signaling pathway related to IFN-gamma. Alternatively, a decrease in transgene expression might be overcome by the use of alternative expression cassettes. Since a lentiviral system was able to achieve long-lasting and stable transgene expression in T cells, a lentivirus vector pseudotyped with SeV envelope proteins could be an ideal vector for use in an activated T-cell-mediated gene therapy strategy.

In general, with the use of $\mathrm{SeV}$, efficient and activated T-cell-directed gene transfer was successfully achieved, indicating that T-cell-mediated gene therapy is more likely to succeed in practice. Moreover, elegant and effective techniques have been developed that can facilitate the preparations of a sufficient number of $\mathrm{T}$ cell lines; included among these techniques is the universal artificial antigen-presenting cell system, which can stimulate $T$ cells by anti-CD3, anti-CD28, and 4-1BB ligand associated with immunological synapses. ${ }^{37}$ In combination with such a technique, the present $\mathrm{SeV}$-derived vector system has therapeutic potential for the clinical application of T-cell-directed gene therapies for use in subjects with various immunological diseases.

\section{Materials and methods}

\section{Animals}

Inbred female C57BL/6 $\left(\mathrm{H}-2^{\mathrm{b}}\right), \mathrm{C} 3 \mathrm{H}\left(\mathrm{H}-2^{\mathrm{k}}\right)$, and BALB/c $\left(\mathrm{H}-2^{\mathrm{d}}\right)$ of Charles River grade mice were obtained from KBT Oriental (Tosu, Japan). 2C transgenic mice (2C-Tg, $\mathrm{H}-2^{\mathrm{b}}$ ), and $\mathrm{L}^{\mathrm{d}}$-reactive $\mathrm{T}$-cell receptor (TCR) transgenic mice $^{27}$ were kindly obtained from Dr K Onoe (Division of Immunology, Institute for Genetic Medicine, Hokkaido University). All mice were humanely maintained in specific-pathogen-free facilities and were fed standard rodent chow and tap water. All mice were used at 7-9 weeks of age. The animal experiments were reviewed by the Ethics Committees for Animal Experiments and Recombinant DNA Experiments, Kyushu University, and were carried out under the 'Guidelines for Animal Experiments' of Kyushu University. The National Institute of Health's 'Principles of Laboratory Animal Care' and 'Guide for the Care and Use of Laboratory Animals' were also followed.

\section{Culture medium}

RPMI 1640 (Sigma, St Louis, MO, USA) medium supplemented with $20 \mathrm{mM} \quad N$-2-hydroxyethylpiperazine- $N^{\prime}$-2-ethanesulfonic acid (HEPES), $0.2 \%$ sodium bicarbonate, $50 \mu \mathrm{M}$ 2-mercaptoethanol (2-ME), $10 \mu \mathrm{g} / \mathrm{ml}$ gentamicine sodium, and 10\% heat-inactivated fetal 
bovine serum (FBS; ICN Biomedicals, Inc., Aurora, OH, USA), was used as the complete medium.

\section{Construction of recombinant SeVs}

SeVs expressing the EGFP gene (SeV-EGFP) or the firefly luciferase gene (SeV-luci) were constructed as previously described. ${ }^{38,39}$ In brief, $18 \mathrm{bp}$ of the spacer sequence $5^{\prime}$ (G)-CGGCCGCAGATCTTCACG-3' with a NotI restriction site was inserted between the $5^{\prime}$ nontranslated region and the initiation codon of the nucleocapsid protein $(\mathrm{N})$ gene. This cloned $\mathrm{SeV}$ genome also contained a self-cleaving rybozyme site from the antigenomic strand of the hepatitis delta virus. The entire complementary DNA (cDNA) coding EGFP (for SeV-EGFP) and luciferase (for SeV-luci) was amplified by polymerase chain reaction (PCR) using primers with a NotI site and new sets of $\mathrm{SeV} E$ and $\mathrm{S}$ signal sequence tags for exogenous genes; then exogenous genes were inserted into the Not I site of the cloned genome. The entire length of the template $\mathrm{SeV}$ genome, including the exogenous genes, was arranged in multiples of six nucleotides (ie, according to the 'rule of six'). ${ }^{40}$ The template $\mathrm{SeV}$ genome with an exogenous gene and plasmids encoding $\mathrm{N}$, phospho- (P), and large (L) proteins (plasmid pGEM-N, pGEM-P, and pGEM-L) was complexed with commercially available cationic lipids, then infected with vaccinia virus vT7-3 into CV-1 or LLMCK cells. ${ }^{41}$ After $40 \mathrm{~h}$ later, the cells were disrupted in three cycles of freezing and thawing and were injected into the chorioallantoic cavity of 10-day-old embryonated chicken eggs. Subsequently, the virus was recovered and the vaccinia virus was eliminated by a second propagation in eggs. The virus titer was determined by hemagglutination assay using chicken red blood cells, ${ }^{42}$ and the virus was stored at $-80^{\circ} \mathrm{C}$ until use.

\section{Monoclonal antibodies ( $m A b)$}

Biotinylated anti-human CD45 RA (HI100) mAb, allophycocyanin (APC)-conjugated anti-murine CD3 (1452C11), murine CD8 (53-6.7), human CD62L (DREG-56) $\mathrm{mAb}$, phycoerythrin (PE)-conjugated anti-human CD3 (UCHT1), human CD4 (RPA-T4), murine CD4 (GK1.5), murine CD8 (53.67) mAb, PE-conjugated-streptavidin, and peridinin chlorophyll- $a$ protein (perCP)-conjugatedstreptavidin were purchased from PharMingen (San Diego, CA, USA). APC-conjugated anti-human CD3 (UCHT1) was purchased from DAKO (Kyoto, Japan). PE-conjugated anti-human CD8 (NU-Ts/c) mAb was purchased from Nichirei (Tokyo, Japan). Anti-2C clonotypic TCR determinant $\mathrm{mAb}$ was purified from the supernatant of the hybridoma (1B2) with a HiTrap protein G column (Amersham Pharmacia Bioscience Inc., Buckinghamshire, UK), and biotinylated with EZLink $^{\mathrm{TM}}$ NHS-LC Biotin (PIERCE Biotechnology Inc., Rockford, IL, USA) in our laboratory.

For T-cell activation, purified anti-mouse CD3 (1452C11), mouse CD28 (37.51), human CD3 (HIT3a), and anti-human CD28 (CD28.2) were purchased from PharMingen (San Diego, CA, USA).

\section{Cell preparation}

For the preparation of murine lymphocytes, the spleens and lymph nodes were collected and kept on ice in complete medium. These tissues were disrupted in the medium by pressing the tissue fragments between two glass slides. Cell suspensions were filtered through stainless-steel mesh and washed twice with the medium. Red blood cells were lysed with ammonium chloride-potassium carbonate lysis buffer. For human peripheral blood lymphocytes (PBL), blood was obtained from healthy donors who gave informed consent, and the lymphocytes were separated by Ficoll Paque ${ }^{\mathbb{R}}$ Plus (Pharmacia Biotech Inc., Wikstroms, Sweden). Viable nucleated cells were counted using a standard trypan blue dye exclusion system.

\section{Establishment of murine and human $T$ cell lines}

For the preparation of alloreactive $\mathrm{T}$ cell lines, lymphocytes $\left(5 \times 10^{7}\right)$ from $\mathrm{C} 57 \mathrm{BL} / 6$ or $2 \mathrm{C}-\mathrm{Tg}$ mice were cocultured with $30 \mathrm{~Gy}\left({ }^{137} \mathrm{Cs}\right.$; Gammacell 40, Atomic Energy of Canada Limited, Ottawa, Canada)-irradiated BALB/c lymphocytes $\left(5 \times 10^{7}\right)$ in a total volume of $10 \mathrm{ml}$ of RPMI 1640 complete medium in a $50 \mathrm{ml}$ flask (35-3014; FALCON, Beckton Dickinson Bioscience, Inc., Franklin Lake, NJ, USA) for 6 days. The activated alloreactive $\mathrm{T}$ cells were stimulated weekly with irradiated BALB/c lymphocytes with supplementation of $10 \mathrm{ng} / \mathrm{ml}$ of human interleukin (IL)-2 (Immuno-Biological Laboratories Co., Ltd, Fujioka, Japan). Since this $\mathrm{T}$ cell line consisted mostly of CD8 T cells, we obtained the CD4 T cell line after the CD8 T cell-depleted lymphocytes had been cocultured with irradiated BALB/c lymphocytes. To prepare the CD8-depleted lymphocytes, freshly isolated lymphocytes were incubated with anti-mouse CD8 (Lyt-2.2; Meiji, Tokyo, Japan) $\mathrm{mAb}$ for $30 \mathrm{~min}$ at $4{ }^{\circ} \mathrm{C}$, followed by incubation with Low-Tox ${ }^{\mathrm{R}}-\mathrm{M}$ Rabbit complement (Cedarlane, Ontario, Canada) for $50 \mathrm{~min}$ at $37^{\circ} \mathrm{C}$. For the murine $\mathrm{T}$ cell line, we used alloantigen-activated $\mathrm{T}$ cells obtained from C57BL/6 or 2C-Tg mice; these cells were stimulated more than three times. For the human T cell line, PBLs $\left(5 \times 10^{6}\right)$ were incubated with $30 \mathrm{~Gy}$ irradiated allogenic PBLs $\left(5 \times 10^{6}\right)$ in a total volume of $1 \mathrm{ml}$ of RPMI 1640 complete medium with supplementation of $10 \mathrm{ng} / \mathrm{ml}$ of human IL-2 for 7 days; then the cells were restimulated for the next 7 days.

\section{Flow cytometry analysis}

The collected murine cells were centrifuged and incubated with $50 \mu \mathrm{l}$ of the supernatant from cultured hybridoma-producing anti-mouse CD16/32 mAb (2.4G2; American Type Culture Collection, Manassas, VA, USA) for $30 \mathrm{~min}$ at $4^{\circ} \mathrm{C}$. This step was excluded in the case of human lymphocytes. The cells were washed in complete medium, incubated with various combinations of $\mathrm{mAb}$ for $30 \mathrm{~min}$ at $4^{\circ} \mathrm{C}$, and then washed twice in complete medium. Biotinylated $\mathrm{mAb}$ was detected using PE- or PerCP-streptavidin. The labeled cells were analyzed using a FACS Caliber, the CellQuest program (Becton Dickinson, San Jose, CA, USA), and the FLOWJO program (TREE STAR, Inc., San Carlos, CA, USA). Just before application to the cytometer, we added $125 \mathrm{ng}$ of propidium iodide (PI) to $250 \mu \mathrm{l}$ of cell suspension in order to detect and exclude dead cells. When we assessed the expression of EGFP in human naive T cells or activated/memory T cells (Figure $4 b$ ), the exclusion of dead cells by PI could not be performed owing to a shortage of fluorescence detector in our four-color FACS system. EGFP was detected in the 
fluorescence 1 . The population of $\mathrm{CD}^{+} \mathrm{CD}^{+} \mathrm{PI}^{-}$cells included viable $\mathrm{CD} 4 \mathrm{~T}$ cells and the population of $\mathrm{CD}^{+} \mathrm{CD}^{+} \mathrm{PI}^{-}$included viable $\mathrm{CD} 8 \mathrm{~T}$ cells, in the murine and in the human cell studies. The population of $\mathrm{CD}^{+} 1 \mathrm{~B}^{+} \mathrm{PI}^{-}$cells included viable $2 \mathrm{C}-\mathrm{Tg} \mathrm{T}$ cells, which were transgenic clonotypic $\mathrm{T}$ cells. Among the population of $\mathrm{CD}^{+}$cells, the population of $\mathrm{CD}^{2} 2 \mathrm{~L}^{+}$ $\mathrm{CD}^{2} 5 \mathrm{RA}^{+}$cells included naive human $\mathrm{T}$ cells and the other populations included activated/memory human T cells. ${ }^{43,44}$

\section{Gene transfer to murine or human T cells by SeV}

For the assessment of transduction efficiency in activated and naive $\mathrm{T}$ cells, $200 \mu \mathrm{l}$ of suspension of murine lymphocytes $\left(2 \times 10^{6} / \mathrm{ml}\right)$ was cultured with $2.5 \times 10^{7}$ PFU of SeV-EGFP for 2 days in 96-well flat-bottom (3860096; IWAKI, Tokyo, Japan) coated with anti-murine $\mathrm{CD} 3 \mathrm{mAb} \quad(15 \mu \mathrm{g} / \mathrm{ml})$ and anti-murine CD28 mAb $(20 \mu \mathrm{g} / \mathrm{ml})$, or the plate was not coated. With respect to human lymphocytes, $200 \mu$ l of suspension of human PBL $\left(4 \times 10^{6} / \mathrm{ml}\right)$ or human $\mathrm{T}$ cell lines $\left(4 \times 10^{6} / \mathrm{ml}\right)$ was cultured with $2.5 \times 10^{7}$ PFU of SeV-EGFP for 2 days in 96well flat-bottom plates coated with anti-human CD3 $\mathrm{mAb} \quad(10 \mu \mathrm{g} / \mathrm{ml})$ and anti-human CD28 mAb $(10 \mu \mathrm{g} / \mathrm{ml})$, or the plate was not coated. Alternatively, after human $\mathrm{T}$ cell lines had been incubated with SeVEGFP at the same MOI for 5, 15, 30, 60, and $90 \mathrm{~min}$ at $37^{\circ} \mathrm{C}$, the cells were vigorously washed and cultured in anti-mouse CD3 and anti-mouse CD28 mAb-coated wells for 2 days. For the assessment of transduction efficiency in alloreactive T cell lines, $100 \mu \mathrm{l}$ of a T cell line $\left(2 \times 10^{6} / \mathrm{ml}\right)$ from $\mathrm{C} 57 \mathrm{BL} / 6$ or $2 \mathrm{C}-\mathrm{Tg}$ mice was cocultured with $100 \mu \mathrm{l}$ of $30 \mathrm{~Gy}$-irradiated lymphocytes $\left(1 \times 10^{7} / \mathrm{ml}\right)$ from $\mathrm{C} 57 \mathrm{BL} / 6$ or $\mathrm{BALB} / \mathrm{c}$ mice, or $200 \mu \mathrm{l}$ of $\mathrm{T}$ cell lines $\left(2 \times 10^{6} / \mathrm{ml}\right)$ from C57BL $/ 6$ or $2 \mathrm{C}$-Tg mice was cultured in anti-mouse CD3 and anti-mouse CD28 mAb-coated 96-well flat-bottom plates with $2.5 \times 10^{7}$ PFU of SeV-EGFP for 2 days. To assess the transduction efficiency in the alloantigen-specific activation of naive $\mathrm{T}$ cells, we used freshly isolated lymphocytes from $2 \mathrm{C}$ - $\mathrm{Tg}$ mice. In alternative experiments, $2.5 \mathrm{ml}$ of a $\mathrm{T}$ cell line $\left(2 \times 10^{6} / \mathrm{ml}\right)$ from $2 \mathrm{C}-\mathrm{Tg}$ mice was stimulated with $2.5 \mathrm{ml}$ of $30 \mathrm{~Gy}$-irradiated lymphocytes $\left(1 \times 10^{7} / \mathrm{ml}\right)$ from C57BL/6 or BALB/c mice with $6 \times 10^{8}$ PFU of SeV-EGFP for 6 days (half of the medium was replaced by fresh medium for 3 or 4 days), and the transduced T cells were washed with fresh medium and restimulated with irradiated C57BL/ 6 or BALB/c stimulator for 6 or 7 days without $\mathrm{SeV}$ (restimulation was performed every 6 or 7 days). To assess the effects of bystander activation, a mixture of $50 \mu \mathrm{l}$ of $2 \mathrm{C}$-Tg-naive lymphocytes $\left(1 \times 10^{7} / \mathrm{ml}\right)$ and $50 \mu \mathrm{l}$ of C57BL/6-naive lymphocytes $\left(1 \times 10^{7} / \mathrm{ml}\right)$ was stimulated with $100 \mu \mathrm{l}$ of irradiated $\mathrm{BALB} / \mathrm{c}, \mathrm{C} 57 \mathrm{BL} / 6$, or C3 H lymphocytes $\left(1 \times 10^{7} / \mathrm{ml}\right)$ with $2.5 \times 10^{7} \mathrm{PFU}$ of SeV-EGFP for 2 days at $37^{\circ} \mathrm{C}$ in humidified air containing $5 \% \mathrm{CO}_{2}$. Expression of EGFP was at a maximum at $48 \mathrm{~h}$ after infection with $\mathrm{SeV}$. The adequate concentration of activating $\mathrm{mAb}$ and optimal dose of $\mathrm{SeV}$ were determined by titration studies. An MOI of 12.5 with $\mathrm{SeV}$ was the lowest dose to transduce EGFP to $\mathrm{T}$ cells with a maximum percentage, and an MOI of over 500 with $\mathrm{SeV}$ had a cytopathic effect on the T cells (data not shown).
Assessment of the number of SeV genome copies in transduced $T$ cells by real-time PCR

A volume of $2.5 \mathrm{ml}$ of a T-cell line $\left(2 \times 10^{6} / \mathrm{ml}\right)$ from $2 \mathrm{C}$ $\mathrm{Tg}$ mice was stimulated with $2.5 \mathrm{ml}$ of $30 \mathrm{~Gy}$-irradiated lymphocytes $\left(1 \times 10^{7} / \mathrm{ml}\right)$ from BALB/c mice with $6 \times 10^{8}$ PFU of SeV-EGFP for 2 or 7 days (half of the medium was replaced by fresh medium at 3 or 4 days). The obtained transduced T cells were washed with fresh medium. The T cells, which were cultured for 2 days, were immediately sorted using a FACS as follows. The T cells, which were cultured for 7 days, were restimulated with irradiated $\mathrm{C} 57 \mathrm{BL} / 6$ or BALB/C stimulator for additional 13 days without $\mathrm{SeV}$ (restimulation was performed every 6 or 7 days). After the transduced $T$ cells were stained with biotin-labeled anti-2C clonotypic TCR and APC-conjugated anti-mouse CD8 followed by PE-conjugated-streptavidin and PI, 2C-Tg T cells cultured for 2 days (ie, those which showed either highly or low expression of EGFP; gate A or B in Figure 3) and 2C$\mathrm{Tg} \mathrm{T}$ cells cultured for 20 days (ie, those with low expression of EGFP; gate C in Figure 3) were sorted using a FACS Caliber and the CellQuest program (Becton Dickinson, San Jose, CA, USA). The purity of each of the sorted populations exceeded $96 \%$. To measure the number of $\mathrm{SeV}$ genome copies in each of the T-cell populations, the total RNA of the sorted cells was extracted with ISOGEN-LS (Nippon Gene, Inc., Toyama, Japan) and was reverse-transcribed using random hexamers (Takara Inc., Osaka, Japan), deoxynucleotide triphosphate (dNTP), and Superscript II reverse transcriptase (Invitrogen, Carlsbad, CA, USA) according to the manufacturer's instructions; real-time quantitative PCR was performed using an ABI PRISM ${ }^{\mathrm{TM}} 7000$ sequence detection system (Applied Biosystems, Branchburg, NJ, USA). To obtain a standard curve for the realtime PCR, a serially 10-fold diluted series (from $10^{8}$ to $10^{2}$ copies) of plasmid DNA, pCR ${ }^{\circledR} 4 \mathrm{TOPO}^{\circledR}$ (Invitrogen, Carlsbad, CA, USA) was used, into which RT-PCR product from the genome of SeV-EGFP was inserted using the TOPO TA Cloning ${ }^{(\mathbb{R}}$ Kit (Invitrogen, Carlsbad, CA, USA). In brief, the genome RNA of SeV-EGFP was extracted with ISOGEN-LS and reverse-transcribed using random hexamers, dNTP, and Superscript II reverse transcriptase. The synthesized cDNA was amplified in a $20 \mu \mathrm{l}$ reaction volume containing $0.5 \mu \mathrm{M}$ of GFPF-sense primer (ie, the region of the EGFP gene open reading frame), 5'ACAACCACTACCTGAGCACCCA GTC3', and $0.5 \mu \mathrm{M}$ of the NPR-antisense primers (ie, the region of the NP gene open reading frame), 5'AACACTGAGACTGTGCTCCTCTGGC ${ }^{\prime}$, dNTP, and $0.5 \mathrm{U}$ Takara Ex Taq ${ }^{\text {TM }}$ DNA polymerase (Takara Inc., Osaka, Japan). The reaction was performed in a T-gradient Thermocycler 96 (Biometra Inc., Goettingen, Germany) for 35 cycles $\left(30 \mathrm{~s}\right.$ at $96^{\circ} \mathrm{C} ; 30 \mathrm{~s}$ at $63^{\circ} \mathrm{C} ; 45 \mathrm{~s}$ at $\left.72^{\circ} \mathrm{C}\right)$. A $10 \mu \mathrm{l}$ aliquot of PCR products (303 bp) was electrophoresed on $1.0 \%$ agarose gel and visualized by ethidium bromide staining. After the slice of agarose containing the cDNA was cut out and extracted using UltrafreeDA $^{\circledR}$ (Millipore, Bedford, MA, USA), the purified cDNA was inserted into $\mathrm{pCR}^{\mathbb{R}} 4 \mathrm{TOPO}^{\mathrm{R}}$ and the chemically competent TOP10 E. coli was transformed with the plasmid and seeded on an LB plate containing $50 \mu \mathrm{g} /$ $\mathrm{ml}$ of ampicillin using the TOPO TA Cloning ${ }^{\mathbb{R}}$ Kit. The plasmid was isolated and purified from a selected colony 
using a Wizard plus SV Minipreps DNA purification system (Promega, Madison, WI, USA) according to the manufacturer's instructions. It was confirmed by sequencing using a DTCS Kit and a CEQ 2000XL DNA Analysis System (Beckman Coulter, Fullerton, CA, USA) that the target PCR product had been inserted into the plasmid DNA. The serially 10-fold diluted series of plasmid DNA (as a standard) and cDNA derived from sorted $2 \mathrm{C}-\mathrm{Tg} \mathrm{T}$ cells (as samples) were amplified in a $50 \mu$ l reaction volume containing $0.9 \mu \mathrm{M}$ of the GFPF2-sense primer (the downstream region of the GFPF-sense primer binding site of the EGFP gene open reading frame), 5'GGATCACTCTCGGCATGGA3 ${ }^{\prime}$, and $0.9 \mu \mathrm{M}$ of the NPR2-antisense primers (the upstream region of the NPR-antisense primer binding site of the NP gene open reading frame), $5^{\prime}$ CGGCCATCGTGAAGATCTG3', $0.25 \mu \mathrm{M}$ of TaqMan $^{\circledR}$ MGB probe, 5'FAM-CAAGTAAAGCTCCGTAGTAA MGB3', and Master mix (Applied Biosystems, Branchburg, NJ, USA). The reaction was performed in an ABI PRISM $^{\mathrm{TM}} 7000$ sequence detection system $\left(120 \mathrm{~s}\right.$ at $50^{\circ} \mathrm{C}$ for one cycle, $600 \mathrm{~s}$ at $95^{\circ} \mathrm{C}$ for one cycle, and, for 40 cycles each, $15 \mathrm{~s}$ at $95^{\circ} \mathrm{C}, 60 \mathrm{~s}$ at $60^{\circ} \mathrm{C}$ ). The numbers of $\mathrm{SeV}$ genome copies of samples were calculated from the standard curve obtained.

\section{Assessment of entry of SeV into naive or activated $T$ cells}

After C57BL/6 lymphocytes $\left(4 \times 10^{6} / \mathrm{ml}\right)$ had been mixed with or without $2000 \mathrm{~mJ}$ of ultraviolet (UV) (UV crosslinker; Pharmacia Biotech Inc., San Francisco, CA, USA)-inactivated SeV-luci $\left(5 \times 10^{8} \mathrm{PFU} / \mathrm{ml}\right)$ at a ratio of 1:1 for $30 \mathrm{~min}$ at $37^{\circ} \mathrm{C}$, the cells were vigorously washed in complete medium and were incubated with SeV-EGFP $\left(2.5 \times 10^{8} \mathrm{PFU} / \mathrm{ml}\right)$ at a ratio of $1: 1$ for $30 \mathrm{~min}$ at $37^{\circ} \mathrm{C}$. After three washes, $200 \mu$ l of the cell suspension $\left(2 \times 10^{6} /\right.$ $\mathrm{ml}$ ) was cultured in 96-well flat-bottom plates coated with anti-murine CD3 $(15 \mu \mathrm{g} / \mathrm{ml})$ and anti-murine CD28 mAb $(20 \mu \mathrm{g} / \mathrm{ml})$ for 2 days without SeV-EGFP. We confirmed that the washing process was sufficient for this experiment, since contaminated $\mathrm{SeV}$ in the final washing medium was less able to transduce EGFP to T cells in the activating wells (data not shown). As a positive control, pretreated cells were cultured for 2 days with $2.5 \times 10^{7}$ PFU of SeV-EGFP in the activating wells. To study the dissociation of attached $\mathrm{SeV}$ from naive $\mathrm{T}$ cells, after $10 \mathrm{ml}$ of C57BL/ 6 lymphocytes $\left(2 \times 10^{6} / \mathrm{ml}\right)$ had been mixed with or without $2 \times 10^{9} \mathrm{PFU}$ of SeVEGFP for $30 \mathrm{~min}$ at $4^{\circ} \mathrm{C}$, the cells were vigorously washed in complete medium and were incubated without $\mathrm{SeV}$ for $0,15,30,45$, and $90 \mathrm{~min}$ at $37^{\circ} \mathrm{C}$. After three washes, the cells were cultured in activating wells for 2 days at $37^{\circ} \mathrm{C}$. As a positive control, the pretreated cells were cultured with $2.5 \times 10^{7}$ PFU of SeV-EGFP.

\section{Statistics}

Statistical significance was determined by one-way ANOVA and Fisher's PLSD test. A value of $P<0.05$ was considered to be statistically significant.

\section{Acknowledgements}

We thank Dr Onoe for kindly providing the 2C transgenic mice and $\mathrm{M}$ Ohara for providing editorial services.

\section{References}

1 Blaese RM et al. T lymphocyte-directed gene therapy for ADASCID: initial trial results after 4 years. Science 1995; 270: 475-480.

2 Altenschmidt U, Moritz D, Groner B. Specific cytotoxic T lymphocytes in gene therapy. J Mol Med 1997; 75: 259-266.

3 Misaki Y et al. Gene-transferred oligoclonal T cells predominantly persist in peripheral blood from an adenosine deaminasedeficient patient during gene therapy. Mol Ther 2001; 3: 24-27.

4 Lam JS et al. Improved gene transfer into human lymphocytes using retroviruses with the gibbon ape leukemia virus envelope. Hum Gene Ther 1996; 7: 1415-1422.

5 Pollok KE et al. High-efficiency gene transfer into normal and adenosine deaminase-deficient $\mathrm{T}$ lymphocytes is mediated by transduction on recombinant fibronectin fragments. J Virol 1998; 72: 4882-4892.

6 Ayuk $\mathrm{F}$ et al. Establishment of an optimised gene transfer protocol for human primary $\mathrm{T}$ lymphocytes according to clinical requirements. Gene Therapy 1999; 6: 1788-1792.

7 Movassagh $\mathrm{M}$ et al. Retrovirus-mediated gene transfer into $\mathrm{T}$ cells: $95 \%$ transduction efficiency without further in vitro selection. Hum Gene Ther 2000; 11: 1189-1200.

8 Kuhlcke K et al. Highly efficient retroviral gene transfer based on centrifugation-mediated vector preloading of tissue culture vessels. Mol Ther 2002; 5: 473-478.

9 Hege KM, Roberts MR. T-cell gene therapy. Curr Opin Biotechnol 1996; 7: 629-634.

10 Tuohy VK, Mathisen PM. T cell design for therapy in autoimmune demyelinating disease. J Neuroimmunol 2000; 107: 226-232.

11 Rosenberg SA et al. Gene transfer into humans - immunotherapy of patients with advanced melanoma, using tumor-infiltrating lymphocytes modified by retroviral gene transduction. $N$ Engl J Med 1990; 323: 570-578.

12 Dardalhon $\mathrm{V}$ et al. Lentivirus-mediated gene transfer in primary T cells is enhanced by a central DNA flap. Gene Therapy 2001; 8: 190-198.

13 Buchschacher Jr GL, Wong-Staal F. Development of lentiviral vectors for gene therapy for human diseases. Blood 2000; 95: 2499-2504

14 Lamb RA, Kolakofsky D. Paramyxoviridae: the viruses and their replication. In: Fields BN, Howley PM et al (eds). Fields of Virology. Lippincott-Raven Publishers: Philadelphia, 1996, pp 1177-1204

15 Collins PL, Chanock RM, Mclntosh K. Parainfluenza viruses. In: Fields BN, Howley PM et al (eds). Fields of Virology. LippincottRaven Publisher: Philadelphia, 1996, pp. 1205-1241.

16 Kumar M, Hassan MQ, Tyagi SK, Sarkar DP. A 45,000-M(r) glycoprotein in the Sendai virus envelope triggers virus-cell fusion. J Virol 1997; 71: 6398-6406.

17 Eguchi A et al. Identification and characterization of cell lines with a defect in a post-adsorption stage of Sendai virusmediated membrane fusion. J Biol Chem 2000; 275: 17549-17555.

18 Glezen WP, Denny FW. Parainfluenza virus. In: Evans AS, Kaslow RA (eds). Viral Infection of Humans. Plenum Medical Book Company: New York, 1997, pp 551-567.

$19 \mathrm{Li} \mathrm{HO}$ et al. A cytoplasmic RNA vector derived from nontransmissible Sendai virus with efficient gene transfer and expression. J Virol 2000; 74: 6564-6569.

20 Yonemitsu Y et al. Efficient gene transfer to airway epithelium using recombinant Sendai virus. Nat Biotechnol 2000; 18: 970-973.

21 Masaki I et al. Recombinant Sendai virus-mediated gene transfer to vasculature: a new class of efficient gene transfer vector to the vascular system. FASEB J 2001; 15: 1294-1296.

22 Masaki I et al. Angiogenic gene therapy for experimental critical limb ischemia: acceleration of limb loss by overexpression of 
vascular endothelial growth factor 165 but not of fibroblast growth factor-2. Circ Res 2002; 90: 966-973.

23 Yamashita A et al. Fibroblast growth factor-2 determines severity of joint disease in adjuvant-induced arthritis in rats. J Immunol 2002; 168: 450-457.

24 Ikeda $\mathrm{Y}$ et al. Recombinant sendai virus-mediated gene transfer into adult rat retinal tissue: efficient gene transfer by brief exposure. Exp Eye Res 2002; 75: 39-48.

25 Shiotani A et al. Skeletal muscle regeneration after insulin-like growth factor I gene transfer by recombinant Sendai virus vector. Gene Therapy 2001; 8: 1043-1050.

26 Moyer SA, Baker SC, Lessard JL. Tubulin: a factor necessary for the synthesis of both Sendai virus and vesicular stomatitis virus RNAs. Proc Natl Acad Sci USA 1986; 83: 5405-5409.

27 Sha WC et al. Selective expression of an antigen receptor on CD8-bearing T lymphocytes in transgenic mice. Nature 1988; 335: 271-274.

28 Markwell MA, Paulson JC. Sendai virus utilizes specific sialyloligosaccharides as host cell receptor determinants. Proc Natl Acad Sci USA 1980; 77: 5693-5697.

29 Okada Y, Tadokoro J. The distribution of cell fusion capacity among several cell strains or cells caused by HVJ. Exp Cell Res 1963; 32: 417-430.

30 Bunnell BA et al. High-efficiency retroviral-mediated gene transfer into human and nonhuman primate peripheral blood lymphocytes. Proc Natl Acad Sci USA 1995; 92: 7739-7743.

31 Chuck AS, Palsson BO. Consistent and high rates of gene transfer can be obtained using flow-through transduction over a wide range of retroviral titers. Hum Gene Ther 1996; 7: 743-750.

32 Chinnasamy $\mathrm{D}$ et al. Lentiviral-mediated gene transfer into human lymphocytes: role of HIV-1 accessory proteins. Blood 2000; 96: 1309-1316.

33 Fehse $\mathrm{B}$ et al. Highly-efficient gene transfer with retroviral vectors into human T lymphocytes on fibronectin. $\mathrm{Br} J$ Haematol 1998; 102: 566-574.

34 Watts TH, DeBenedette MA. T cell co-stimulatory molecules other than CD28. Curr Opin Immunol 1999; 11: 286-293.
35 Kato A et al. Y2, the smallest of the Sendai virus C proteins, is fully capable of both counteracting the antiviral action of interferons and inhibiting viral RNA synthesis. J Virol 2001; 75: 3802-3810.

36 Biron CA, Sen GC. Interferons and other cytokine. In: Fields BN, Howley PM et al (eds). Fields of Virology. Lippincott-Raven Publishers: Philadelphia, 1996, pp 321-351.

37 Maus MV et al. Ex vivo expansion of polyclonal and antigenspecific cytotoxic T lymphocytes by artificial APCs expressing ligands for the T-cell receptor, CD28 and 4-1BB. Nat Biotechnol 2002; 20: 143-148.

38 Kato A et al. Initiation of Sendai virus multiplication from transfected cDNA or RNA with negative or positive sense. Genes Cells 1996; 1: 569-579.

39 Sakai $\mathrm{Y}$ et al. Accommodation of foreign genes into the Sendai virus genome: sizes of inserted genes and viral replication. FEBS Lett 1999; 456: 221-226.

40 Kolakofsky D et al. Paramyxovirus RNA synthesis and the requirement for hexamer genome length: the rule of six revisited. J Virol 1998; 72: 891-899.

41 Fuerst TR, Niles EG, Studier FW, Moss B. Eukaryotic transientexpression system based on recombinant vaccinia virus that synthesizes bacteriophage T7 RNA polymerase. Proc Natl Acad Sci USA 1986; 83: 8122-8126.

42 Yonemitsu Y, Kaneda Y. Hemagglutinating virus of japan liposome-mediated gene delivery to vascular cells. In: Baker AH (ed). Vascular Disease: Molecular Biology and Gene Therapy Protocols. Humana Press: Totowa, NJ, 1999, pp 295-306.

43 Picker LJ et al. Control of lymphocyte recirculation in man. I. Differential regulation of the peripheral lymph node homing receptor L-selection on $\mathrm{T}$ cells during the virgin to memory cell transition. J Immunol 1993; 150: 1105-1121.

44 Ostrowski MA et al. Both memory and CD45RA+/CD62L+ naive $\mathrm{CD} 4(+) \mathrm{T}$ cells are infected in human immunodeficiency virus type 1-infected individuals. J Virol 1999; 73: 6430-6435.

45 Jin $\mathrm{CH}$ et al. Recombinant Sendai virus provides a highly efficient gene transfer into human cord blood-derived hematopoietic stem cells. Gene Therapy 10: 272-277. 